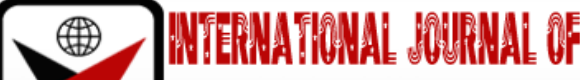

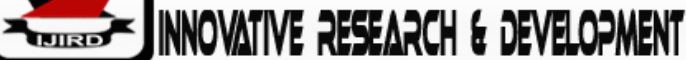

ISSN $2278-0211$ (Online)

\section{The Influence of Building Function Characteristics on City Wallk Utilization on Slamet Riyadi Street, Surakarta, Indonesia}

\begin{tabular}{c} 
Tri Hartanto \\
Lecturer, Architecture Study Program, \\
Tunas Pembangunan University of Surakarta, Indonesia \\
Abito Bamban Yuuwono \\
Lecturer, Architecture Study Program, \\
Tunas Pembangunan University of Surakarta, Indonesia \\
\hline
\end{tabular}

\begin{abstract}
:
Since 2007, the city of Surakarta has built an area for pedestrians or pedestrian paths which is often referred to as a city walk. City walk is a public open space based on the idea of raising the existing potential of Surakarta and growing with the slogan "Solo Past As Solo Future". The current state of the city walk is widely used for street vendors (PKL) activities, vehicle parking activities, pedicab driver activities, bicycle / motorbike circulation. So this research is important to know the use of city walk space and what factors influence the low utilization of city walk space by pedestrians. The research methodology used in this study is a qualitative method, because the variables that affect this study are qualitative variables. The analytical method to describe the phenomena that occur in the research area is carried out with grounded theory. With the coding technique procedures / stages, namely open coding, axial coding and selective coding to analyze various data according to the phenomena that occur in a city walk. The results showed that the use of the city walk was influenced by the function of the building. Buildings with commercial functions have a higher activity level than non-commercial buildings. The higher the activity level in the building and the shade of the city walk space, the higher the level of space utilization activity.
\end{abstract}

Keywords: Utilization, city walk, building function, surakarta

\section{Introduction}

Since 2007, the city of Surakarta has built public open space areas for pedestrians or pedestrian paths which are often referred to as city walks. It was built on Jalan Slamet Riyadi, which is the main street in the city of Surakarta, starting from the Purwosari area to the city boulevard in the Gladag area. On March 8, 2008, this city walk was officially opened for use by the Mayor of Surakarta, which he called the "Solo City Walk". The Solo City Walk is a project based on the idea of raising Surakarta's existing potential and growing with the slogan "Solo Past As Solo Future". The current condition of the city walk is used by the people around this area for various activities such as parking activities, motorbike parking as well as car parking, and rickshaws. People sell food and drinks with a tents and cart (PKL) system, very much in the city walk area. The city government's efforts to discipline it by installing signs and portals on the city walk route have not been able to solve the existing problems.

The current daily condition of the city walk is used by the people around this area for various activities such as parking, motorbike parking as well as car parking, and rickshaws. People sell food and drinks with a tents and cart (PKL) system, very much in the city walk area. Shop owners use the city walk space for their storefronts, flower bouquet shop employees also use this route as a place to work from flower arrangement to delivery. Indeed, previously this area was a slow lane and a parking area. In addition, at certain times, many school children using bicycle modes of transportation use the city walk as a shortcut. Rapoport (1977) suggests that the pedestrian lane environment as long as it has a function as a circulation space, also has the capacity to accommodate the emergence of other activities that are always there. The appearance of these activities does not always create negative things because walking also requires physical and visual stimulation to maintain a feeling of joy so as not to quickly feel tired because of boredom (Utermann, 1987).

City space, both in the form of fields and corridors / networks, is one of the very important elements of urban design in controlling the quality of the ecological and social environment (Shirvani, 1985). However, in reality, these days are increasingly pressed by economic interests. Most of the shops along this area use the city walk as a place for daily activities. The city government's efforts to curb by installing a portal on the city walk route have not been able to solve the existing problems. If it is allowed, one of the functions of the city walk is as a medium for movement of pedestrians / pedestrians, their comfort will be disturbed.

Pedestrian paths or walking paths, are special places or paths for pedestrians. Both Shirvani (1985) and Lynch (1987) suggest that pedestrians are part of public space and are an important aspect of an urban space, both in the form of 
a square (field-open space) and street (corridor). If the road is designed as a public space by providing a dominant portion for pedestrian activities, it is necessary to limit the function of motorized vehicle transportation. The development of this road section can use the city walk or mall approach. According to Wicaksana (2007), human behavior in architecture and urban design is a means of controlling the success of a design, its effect on the human built environment. According to Rapoport (1997), evaluation of decisions, behavior and so on is the result of environmental perceptions that are strongly influenced by human background and human physical conditions. The behavior of each individual is always related to the environment, because the process of shaping that behavior occurs in a certain environment.

\section{Research Method}

The research methodology used in this study is a qualitative method. The qualitative method was chosen because some of the variables affecting this study were qualitative variables. The analytical method to describe the phenomena that occur in the research area is carried out with grounded theory. With the procedures / stages of coding techniques, namely open coding, axial coding and selective coding (Corbin \& Strauss, 2003) to analyze various data according to the phenomena that occurred in the city walk Jalan Slamet Riyadi Surakarta. The analytical method used is qualitative inductive analysis with a background of theories in urban design and human behavior in architecture. The data of each object to be typologized based on variations in the use of space, aspects related to the physical outer space (city walk) and aspects of human activities in it. In the process of analyzing data, the stages of coding the raw data into theory are carried out, the principles of theoretical analysis are based on the process of categorization into defined concepts to mark these categories (Corbin, 2015).

Based on the project documents of the Surakarta City Planning Office (DTK), Solo City Walk is divided into seven segments, each of which is equipped with public facilities such as stadiums, shopping centers, recreational parks, traditional markets, culinary tours and seatting groups to rest. However, in this study it is limited to only six segments studied, from segments 1-6 (located on Jalan Slamet Riyadi) Surakarta. Data collection and analysis are also based on the conditions of each segment. The planning concept of each segment has different potentials and functions. Segment 1 (Purwosari-Brengosan) is a specification for Shopping and Culinary Tourism, Segment 2 (Brengosan-Gendengan) is a culinary tourism specification, Segment 3 (Gendengan-Maladi Stadium) is a tourist specification for Architecture, Segment 4 (Stadium Maladi-Ngampeman) is a specification for cultural tourism, art, and Architecture, Segment 5 (Ngapeman-Yos Sudarso), a shopping and cultural tourism specification, and segment 6 (Yos Sudarso-Gladag / Keraton). Shopping and cultural tourism specifications.

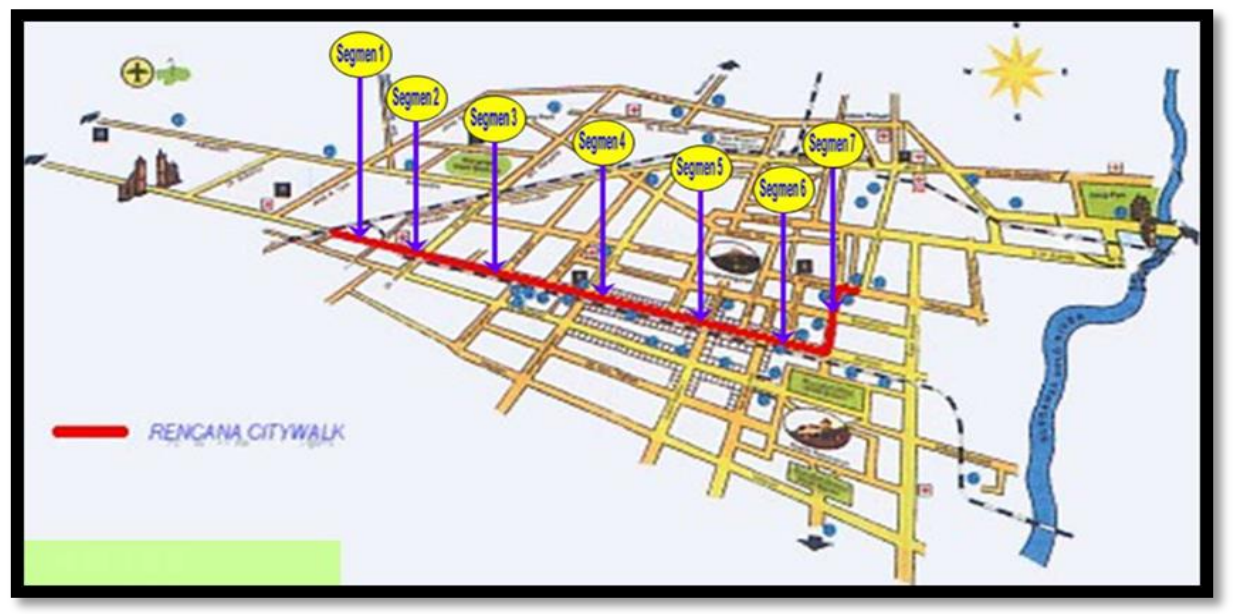

Figure 1: City Walk Segment Distribution Map Jl.Slamet Riyadi Source: Surakarta City Planning Office

\section{Result and Discussion}

\subsection{Initial Conditions of City Walk and Its Utilization}

Starting from the slow lane on the south side of Jalan Slamet Riyadi, the city government of Surakarta initiated to convert it to a pedestrian route or better known as a city walk. The hope is that apart from being a public space for the people of Surakarta and its surroundings, one day this pedestrian path is expected to be able to raise the image of tourism in the city of Solo. The city walk was originally built with the concept of pedestrian space made with paving with colorful patterns, coupled with cultural spots and seats at several points. However, the condition of the city walk that has been made in such a way is actually used by the people of Solo as a means of transportation for bicycles, even motorbikes often pass this route. Street vendors also take advantage of the shady places to sell, so that pedestrians are less comfortable using this city walk. The following are various uses of the city walk route by the people of Solo and its surroundings from morning to afternoon. 


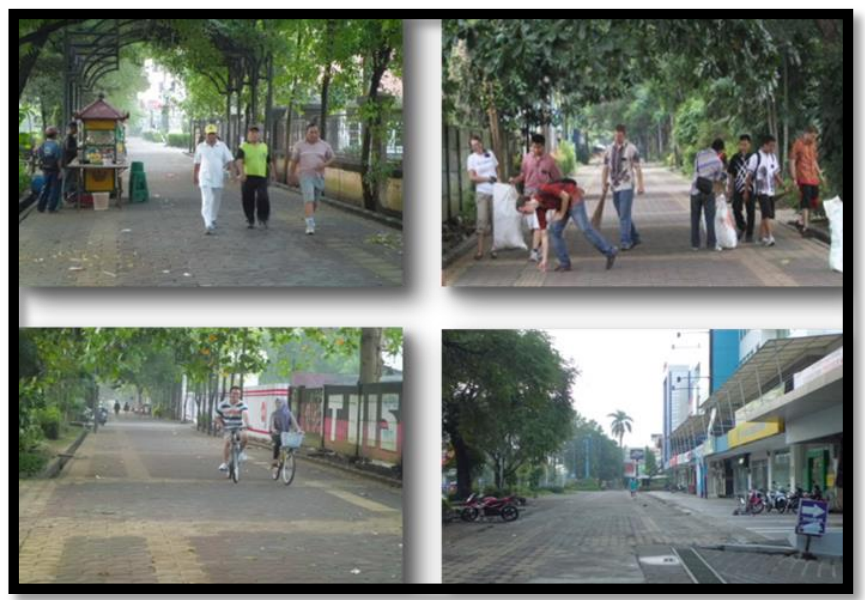

Figure 2: Conditions of City Walk Use in the Morning

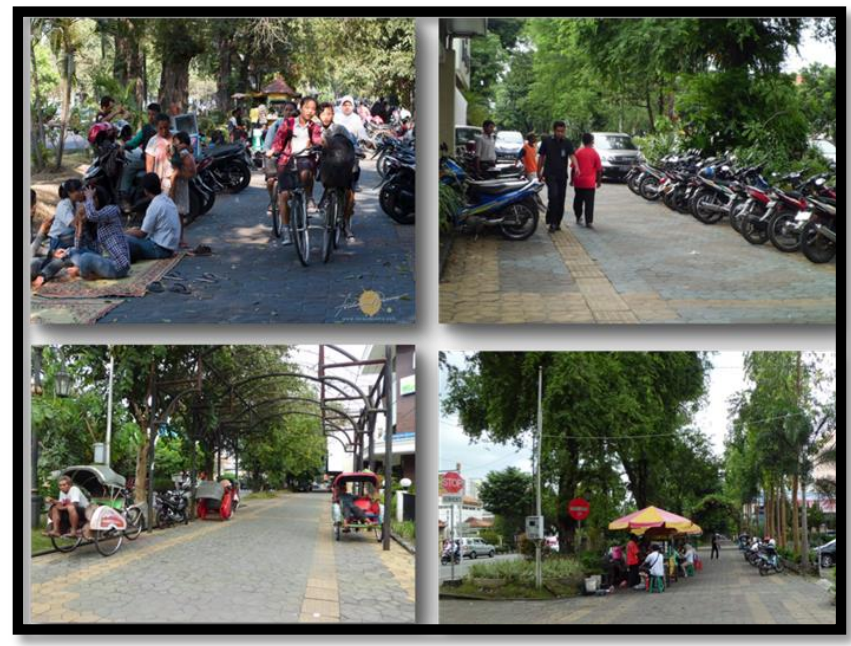

Figure 3: Conditions of City Walk Utilization during the Day

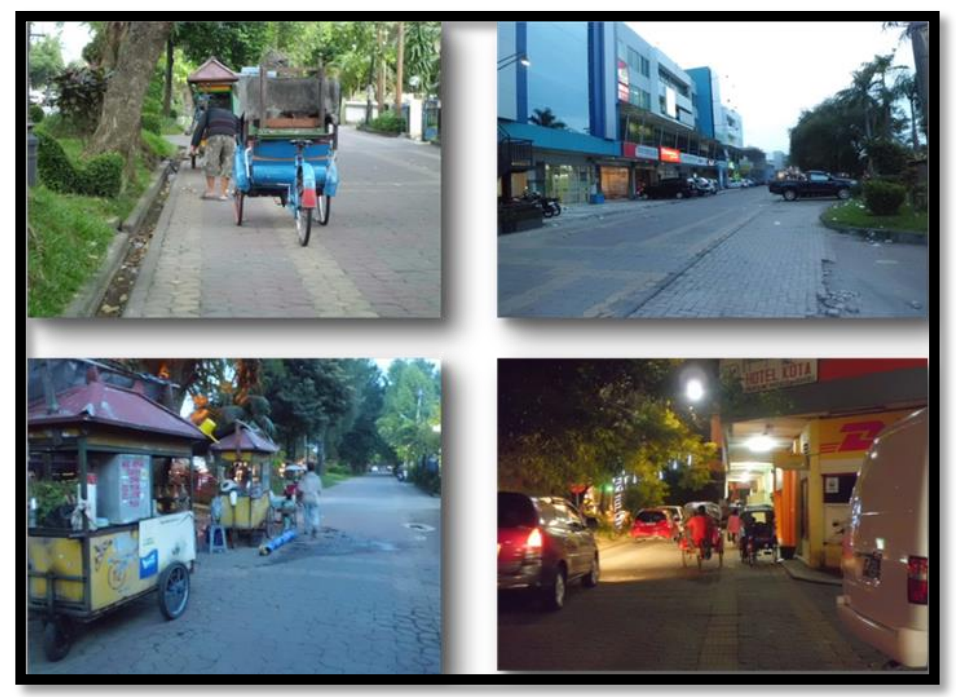

Figure 4: Conditions of City Walk Utilization during the Day

\subsection{Initial Condition of City Walk after 2020 Renovation}

Early 2020 became a new chapter for the city walk of Jalan Slamet Riyadi. The pedestrian area on the main road in Solo City is officially functioned as a parking area by the Surakarta City Government. After completing a series of field studies and surveys, the city government began to implement the plan to expand the city walk parking space that was spawned since October 2018. Based on the initial scenario, the Gendengan intersection to the Gladag area was the location chosen by the City Government as the additional on-street parking area. . The city walk segment is in line with the study by the consultant team, which last year recommended the Purwosari to Gladag intersection as a parking point. The city government has also implemented a number of rules that prospective users of parking services on city walks must obey. Understandably, if allowed to park carelessly, vehicles parked in the area have the potential to interfere with the main function of a city walk as a pedestrian lane or traffic around it. Moreover, since the beginning, the city government has 
committed to maintaining the main function of the city walk. The operation of the dedicated car parking area is also limited. Namely, 17.00 to 06.00 . Even during a Car Free Day (CFD), an official city government event held on a city walk or other important purpose, parking activities must stop completely. The next rule is the technicality of getting in and out of vehicles from and to Jalan Slamet Riyadi. Especially for four-wheeled vehicles, they can directly enter the parking area between the trees by walking backwards facing the road. The position of the vehicle must also be oblique.

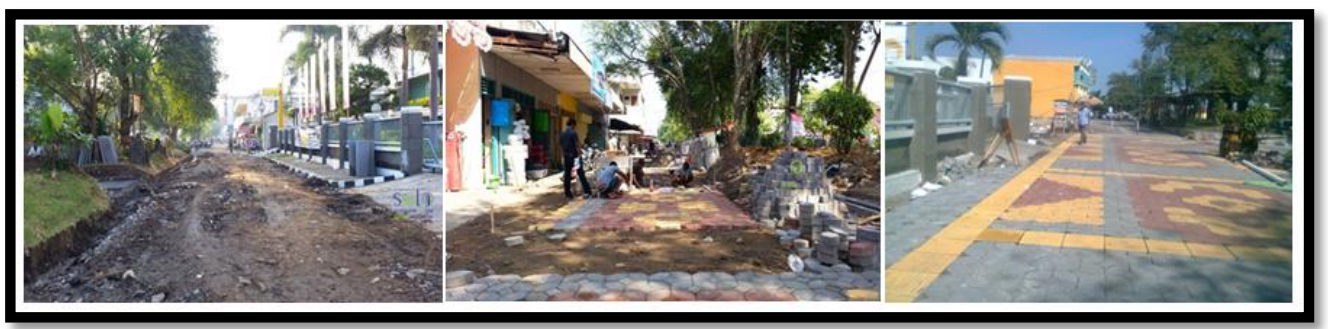

Figure 5: Kondisi Renovasi Jalur City Walk Jl.Slamet Riyadi Segmen 4

\subsection{Building Function Data}

Along the city walk, which extends from Purwosari to Gladag, there are many buildings with various forms of appearance and function. However, broadly speaking, it is divided into two, namely buildings with commercial / commercial functions and buildings with non-commercial / residential / office functions.

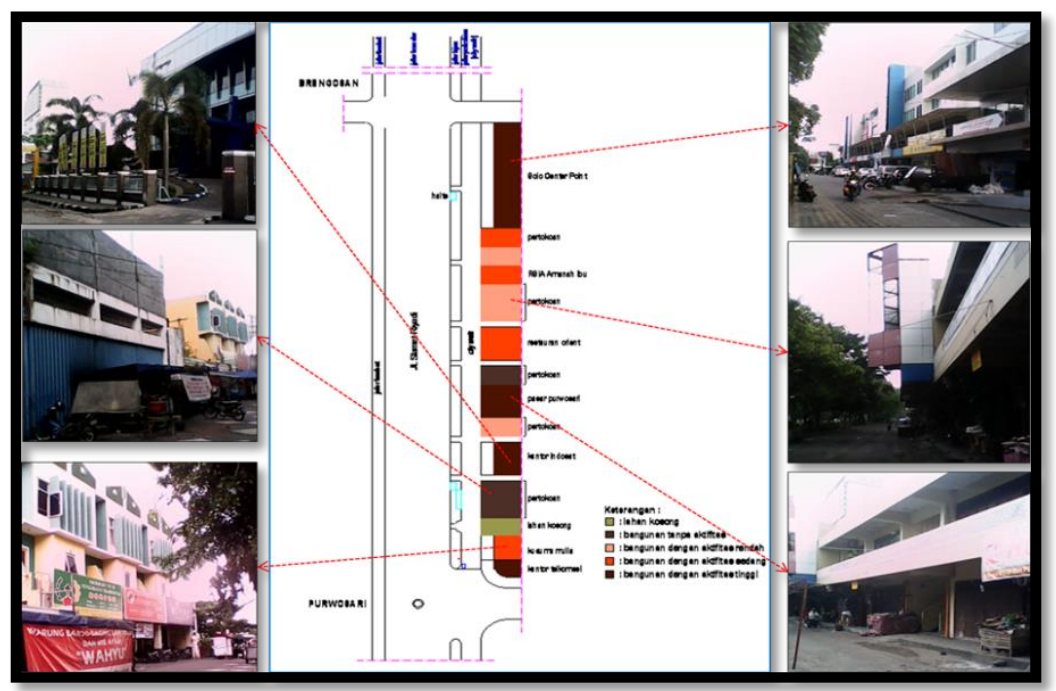

Figure 6: Condition of Building Appearance on City Walk Line Jl.Slamet Riyadi Segment 1

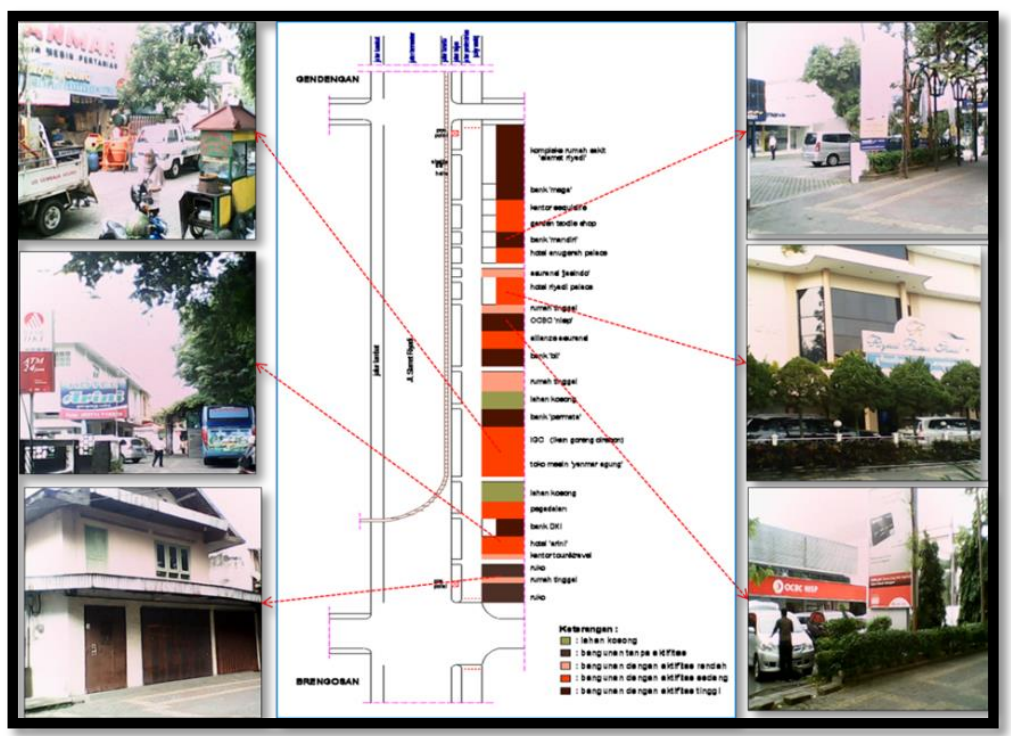

Figure 7: Condition of Building Appearance on City Walk Line Jl.Slamet Riyadi Segment 2 


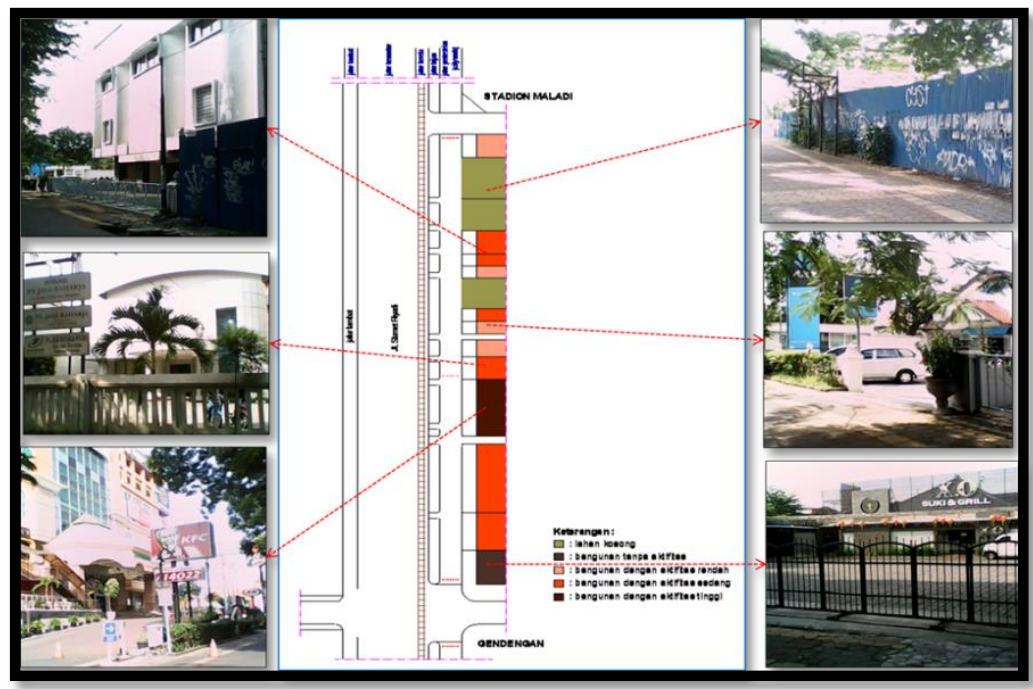

Figure 8: Condition of Building Appearance on City Walk, Jl.Slamet Riyadi Segment 3

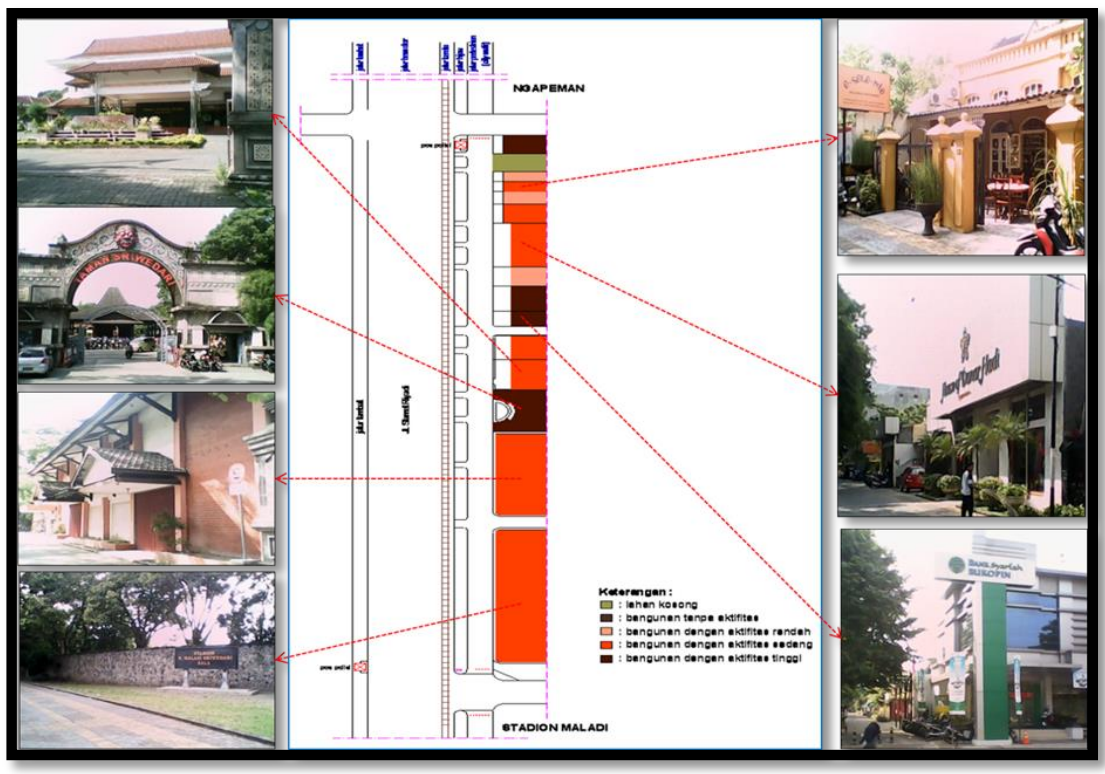

Figure 9: Condition of Building Appearance on City Walk Line Jl.Slamet Riyadi Segment 4

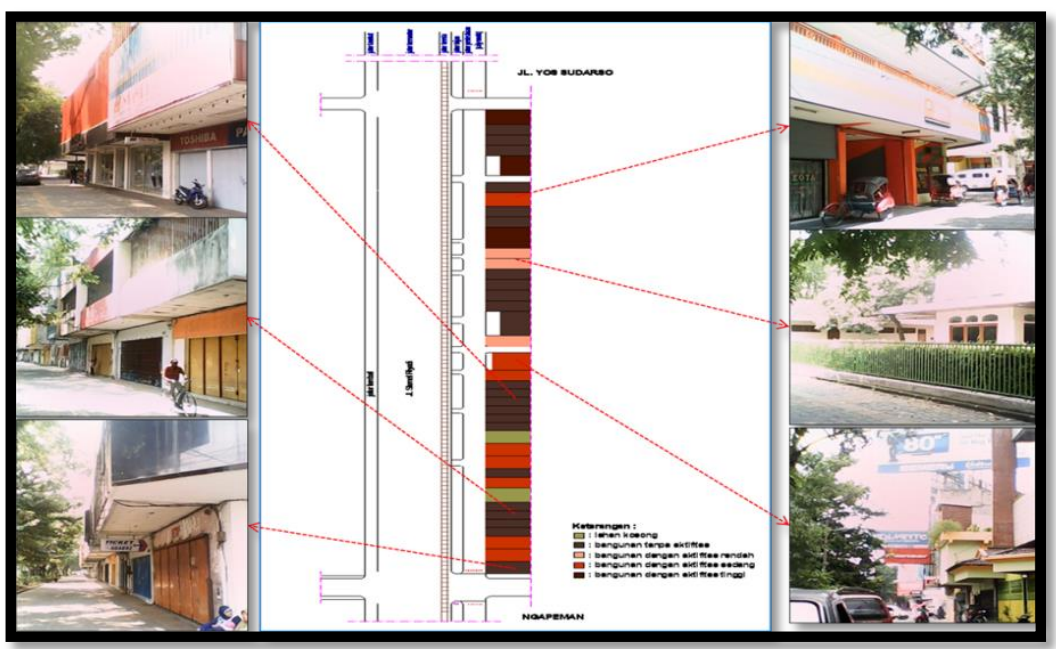

Figure 10: Condition of Building Appearance on City Walk Line Jl.Slamet Riyadi Segment 5 


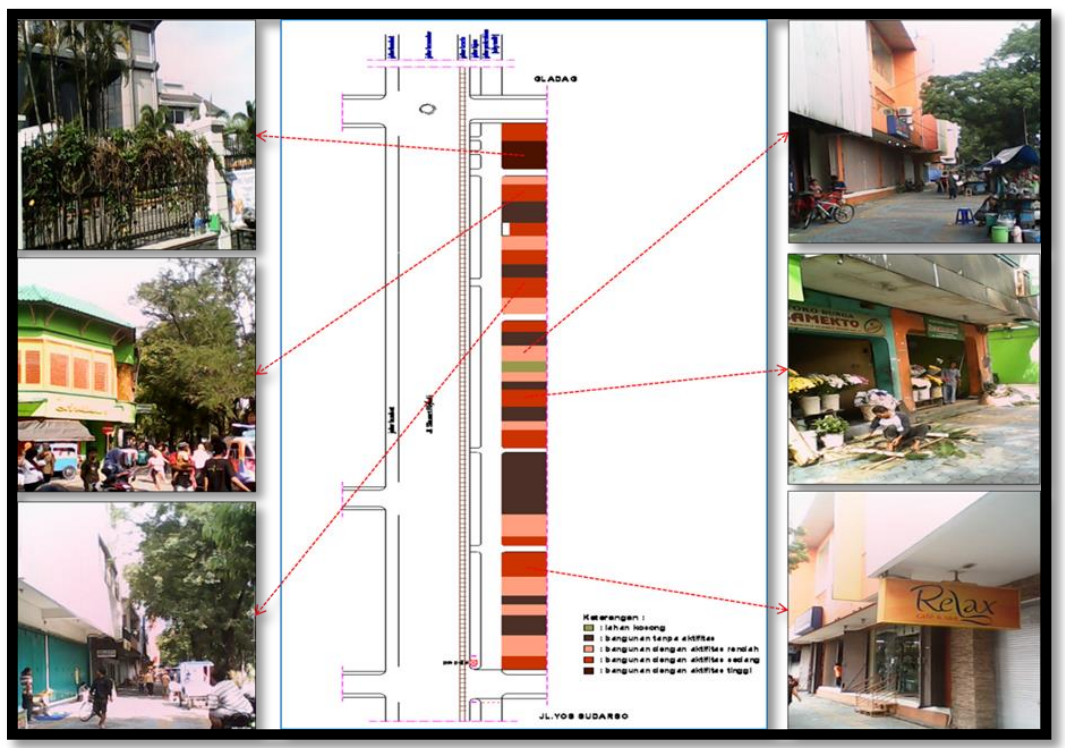

Figure 11: Condition of Building Appearance on City Walk Line Jl.Slamet Riyadi Segment 6

According to Wicaksana (2007), human behavior in architecture and urban design is a means of controlling the success of a design, its effect on the human built environment. As an explanation, the design of a public open space that is shady and comfortable can affect the behavior of visitors who want to relax in open spaces but get comfortable, so there is no need to do relaxing activities in the room. Human behavior is influenced by the surrounding environment and behavior itself is a realization of the intention to carry out activities in a tangible form and a reflection of one's attitude. According to Rapoport (1997: 9), evaluation of decisions, behavior and so on is the result of environmental perceptions which are strongly influenced by human background and human physical conditions. The behavior of each individual is always related to the environment, because the process of shaping that behavior occurs in a certain environment. Environmental conditions and conditions that affect human behavior in it are expressed by Windley and Scheid in Weisman, (1987) which are translated into elements of environmental attributes, namely:

- Sensory stimulation, or sensory stimulation, the quality and intensity of stimulation as an experience felt by the human senses.

- Comfort or comfort, a state that gives a feeling of "in accordance" with the activities.

- Activity or activity, a feeling of intensity in a behavior that continuously occurs in an environment.

- Crowdedness or tightness, a feeling of density in an environment.

- Sociality or sociality, the level of one's ability to make social relations in a setting.

- Privacy or privacy, the ability to monitor the flow of visible and audible information, either from or in an environment.

- Control or control, the condition of an environment to create personality, create territory and limit space.

- Accessibility, the ease of moving through and using the environment, which is related to circulation (road) and visuals.

- Adaptability, the ability of the environment to accommodate different behaviors that did not exist before.

- Legibility, the ease for someone to know or understand the key elements and relationships in an environment that cause that person to find a direction or a way.

- Meaning or meaning, the ability of an environment to present individual or cultural meanings to humans.

According to Robert Beckley (1979), the use of a building for the city is in giving it special characteristics. In fact a city is formed by a number of buildings, city design has a concern in contributing to one another. Beckley divides the buildings into four groups in a knitted city, namely;

- building as a generating element

- building as a determining element of space

- buildings as points of interest and landmarks, and

- buildings as views and facades.

As a place of human activity, a building can act as an element for generating other activities around it. Buildings and open space are the two elements that form the pattern of space and give the shape of a city character. 


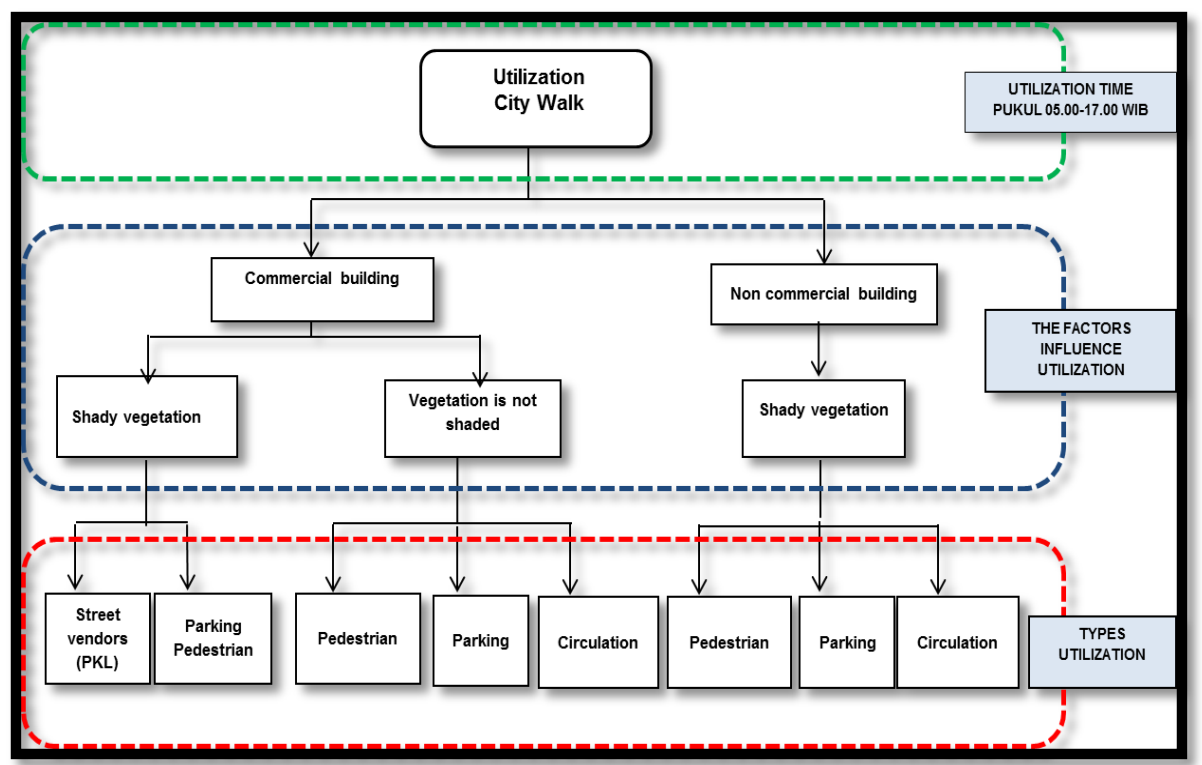

Figure 12: Grounded Theory Process: Open Coding, Axial Coding, and Slective Coding

\section{Conclusion}

The use of a city walk is strongly influenced by the surrounding conditions, namely the presence of buildings and shade created by vegetation along the green lane. The higher the level of activity in the building and the creation of shade around it, the higher the level of city walk space utilization.

As a place of human activity, a building can act as an element for generating other activities around it. Buildings and open space are the two elements that form the pattern of space and give the shape of a city character.

The findings of this study include the use of city walk space in the form of street vendors, pedestrian, parking and circulation activities which are influenced by the presence or function of buildings (commercial and non-commercial) in the vicinity. This is in accordance with the theory of Robert Beckly (1979), that one of the uses of a building for the city is as an element for generating other activities in its surroundings.

\section{References}

i. Anonim, Kajian Hukum Tentang City Walk, 2006.

ii. Azzahra. HJ, Astuti. W, Rini. EF. 2018. Jurnal Pembangunan Wilayah dan Perencanaan Partisipatif:Komponen Keterpaduan Objek Wisata di Kawasan City Walk Slamet Riyadi Ditinjau dari Sistem Pariwisata. Universitas Sebelas Maret (UNS). Vol 13, No 1 (2018). 1858-4837 (Print). 2598-019X (Online)

iii. Budihardjo, Eko(2005). Tata Ruang Perkotaan, PT Alumni, Bandung.

iv. Carmona dkk. (2003). Public Space Urban Space: The Dimension of Urban Design. Architectural Press. London.

v. Carr. Stephen, Mark Franchis, Leane G. Rivlin and Andrew M. Store (1992). Public Space, Press Syndicate of University of Cambridge, Australia.

vi. Davies-Lewelyn (2000). Urban design Compendium I, Housing Corporation, English Partnership.

vii. Djumiko. 2013. Jurnal Teknik Sipil dan Arsitektur: Fungsi City Walk Jalan Slamet Riyadi Kota Surakarta, Fakultas Teknik Universitas Tunas Pembangunan Surakarta, Vol. 13 No. 17 (2013)

viii. Mustika, H. 2017. Jurnal Pembangunan Wilayah dan Kota: Peranserta Stakeholder Dalam Membentuk City Branding The Spirit Of Java Di Jalan Slamet Riyadi Surakarta.

ix. Prabasmara, PG. Wahyu Subroto, T.YW. Rochyansah, MS. 2018. Jurnal Arsitektur Pendapa: Konsep livabilitas sebagai dasar optimalisasi ruang publik Studi kasus: Solo City Walk, Jalan Slamet Riyadi, Surakarta, Universitas Widyamataram, Vol 1, No 2 (2018). DOI: https://doi.org/10.37631/pendapa.v1i2.110

x. Royan. N, Sarwandy, MH. Rahmadona, E. 2019. Bearing : Jurnal Penelitian dan Kajian Teknik Sipil: Analisis Dampak Lalu Lintas Pengembangan Soma City Walk Jalan Veteran Palembang. Jurusan Teknik Sipil, Fakultas Teknik, Universitas Muhammadiyah Palembang. P-ISSN : 2085-6261. E-ISSN : 2623-1409. Vol 6, No 2 (2019)

xi. Rapoport, Amos (1977), Human Aspects of Urban Form; Towards a Man Environment Approach to Urban Form and Design. Oxford, Pergamon Press.

xii. Shirvani, Hamid. (1985). Urban Design Process, Van Nistrand Reinhold Company, New York.

xiii. Wirosandjojo (1985). Urban Space, Mall, City Walk dan PKL,http/www.PKL.pdf. 